\title{
Testing the effects of financial literacy on debt behavior of financial consumers using multivariate analysis methods
}

\author{
Vlasta Bahovec ${ }^{1}$, Dajana Barbić, ${ }^{1, *}$ and Irena Palić ${ }^{1}$ \\ ${ }^{1}$ Faculty of Economics and Business, University of Zagreb \\ Trg J. F. Kennedy 6, 10000 Zagreb, Croatia \\ E-mail: 〈\{vbahovec, dcvrlje, ipalic\}@efzg.hr〉
}

\begin{abstract}
The aim of this paper is threefold. First, to detect and categorize Croatian financial consumers' financial literacy and analyze whether the different levels of financial literacy is statistically significant in terms of socio-demographic characteristics. The second objective is determining whether a respondent's debt behavior differs based on their financial literacy. Further, the paper aims to examine sources of different debt behavior in relation to financial literacy. Cluster analysis is used to categorize financial literacy and determine whether a respondent's financial literacy differs due to gender and level of disposable income. Here, the nonparametric chi-square test is applied. The effects of financial literacy on debt behavior are investigated using a rank-based nonparametric test, specifically the Kruskal Wallis $H$ test. Finally, the paper will examine the source of differences in debt behavior based on different levels of financial literacy, and a post hoc analysis using Dunnett's $C$ test will be conducted. The results suggest that respondents exhibit different debt behavior due to different levels of financial literacy. In addition, the level of disposable household income per household member was found to be statistically insignificant with respect to different levels of financial literacy, while such levels were found to be statistically significantly different when compared to a respondent's gender.
\end{abstract}

Key words: cluster analysis, Kruskal Wallis H test, Dunnet's C test, financial literacy, debt behavior

Received: October 10, 2014; accepted: February 10, 2015; available online: October 31, 2015

DOI: $10.17535 /$ crorr.2015.0028

\section{Introduction}

The problems related to financial illiteracy are increasingly becoming a topical issue. There are many reasons why both public and academics are focused on this specific field of research. One of the key reasons is the current economic crisis, which has highlighted the main deficiencies stemming from financial illiteracy. The crisis has pointed out the importance of understanding financial

${ }^{*}$ Corresponding author. 
products and services and the risks of engaging in financial activities without the necessary level of financial knowledge and skills. There is mounting evidence that people are in terms of financial literacy undereducated and thus unfamiliar with even the most basic financial concepts. Consequently, in the developed countries there is a growing body of literature investigating the concept of financial literacy, its determinants as well as its possible effects on the wellbeing of households (see, for example, [4, 13, 14]).

However, the literature measuring financial literacy in small transition economies like Croatia is rather limited. Lack of financial knowledge and financial skills of individuals and households can place them in a very difficult financial situation. Specifically, in recent years, a lot of people have found themselves in situations where they have been unable to make their loan repayments and consequently have reported an excessive financial burden due to bad debt.

\section{A theoretical background and overview of literature}

\subsection{Financial literacy and excessive debt}

Financial literacy indicates how well individuals understand financial concepts and it shows their ability to interpret financial data correctly [8]. Moreover, financial literacy reflects an individual's ability to understand financial concepts, financial products and services and providing an ability to control personal financial resources. Although financial literacy as a concept is rather new and connected mainly to recent developments, financial education as a possible cure for fixing poor financial decisions and behavior is not. It has its roots in the 1950s and 1960s, when the US government started to mandate inclusion of economics, personal finance and similar consumer education topics in the K-12 educational curriculum [3]. According to the findings of previous studies, there seems to be a positive relationship between financial education and financial behavior [17]. Thus, financial literacy should increase an individual's ability to independently manage and plan personal finances. In other words, financial literacy should help individuals and households to manage better their personal finances, including better debt management.

Due to rapid financial development, which has taken place in recent years, substantial increase in the variety and the use of financial instruments has been noticeable throughout the world [18]. In line with the "democratization" of loans, consumer debt loads have exploded with the use of credit cards, mortgages, consumer loans and similar products [6]. In Croatia, the development of financial institutions has meant that loans have become products easily available to many people, even those who may be considered as risky clients [11]. Consequently, many households are highly indebted. In 2010, household 
using multivariate analysis methods

debt exceeded 40\% of GDP. In 2013 and 2014, it started to decrease and reaching a level slightly below $40 \%$. The publication of [5] shows that, compared to previous years, debt indicators slightly improved in 2013 and 2014 due to a deleveraging trend, increase in household savings and decrease in disposable income. Nonetheless, regardless of these improvements, the exposure of Croatian households to macroeconomic and financial risks, i.e. decreasing disposable income and an increasing unemployment rate, is still rather high, and may increase even further in the near future [5].

From the aspect of developing and maintaining financial security and financial wellbeing, people should take on debt only to the extent their current and future income would allow. In other words, one should have the financial reserves to pay for living expenses, while still having enough money to meet loan repayments. According to [16], person or household becomes indebted when defaulting on payments or when precariously approaching defaulting. From a macroeconomic perspective, the usual indicator of the households' indebtedness refers to defaulting on payments, debt burden indicators and the number of loan repayment obligations [2].

\subsection{Financial literacy and debt behavior}

Recent research concerning this specific topic has shown that high levels of financial illiteracy are usually associated with high levels of indebtedness. Relevant research by [1] provides evidence that financial competence is directly related to the ability to make better decisions regarding loans. The conclusion is that individuals who learn more about credit cards should make better choices on loans. On the contrary, people with lower levels of financial literacy usually make poor loan decisions. The research of [13] reported that low levels of financial literacy among loan users are associated with high loan costs. Similarly, [19] found that financial illiteracy is connected to debt accumulation and [15] reported a correlation between low levels of literacy and poor mortgage choices. In their research, [4] concluded that the key predictor for loan outcomes is financial behavior determined by the level of financial literacy. Moreover, in their study [14] reported that people with low financial literacy are found to be more likely to have debt problems. The findings of the research conducted by [18] suggest that a consumer with a higher level of financial literacy is less likely exhibit excessive borrowing behavior. The relationship between debt literacy, financial experience and debt levels implies that financially illiterate people have a higher risk of indebtedness [13]. 


\section{Empirical analysis of the impact of financial literacy on debt behavior in Croatia}

According to [13], financial sophistication presents one of the key factors that may cause over borrowing and indebtedness of individuals and households. They reported that low financial literacy is usually connected with high cost of borrowing. Moreover, in their study, [18] concluded that financial consumers possessing different levels of financial literacy behave differently in regard to borrowing decisions, whereas financial consumers with high levels of financial literacy were less prone to demonstrating excessive borrowing behavior. In their research, [13] reported that financial literacy is widespread but prevalent among specific groups, such as people with low income and women. The basic assumptions that we hypothesized in this research are that levels of financial literacy vary significantly with respect to gender and income; and that a person's indebtedness varies significantly with respect to the level of financial literacy.

\subsection{The multivariate methods used in empirical analysis}

In this research, we used both qualitative and quantitative research methods to measure the effects of financial literacy of Croatian citizens with respect to their level of indebtedness. The K-means cluster analysis was applied to categorize the levels of financial literacy of the surveyed sample. Cluster analysis is the analytical technique for developing meaningful subgroups of individuals or objects. The objective of cluster analysis is to classify a sample of entities into a small number of mutually exclusive groups based on similarities among the entities. In cluster analysis, the groups are not predefined, but instead the technique is used to identify groups. For a detailed explanation of cluster analysis, see [10]. The chi-square test was applied with the objective of determining whether levels of financial literacy vary with respect to gender and monthly income per person in a household. The chi-square test analysis is used to examine the relationship between two discrete variables. In the $\chi^{2}$ analysis, the null hypothesis generates expected frequencies against which observed frequencies are tested. If the observed frequencies are similar to the expected frequencies, then the value of the $\chi^{2}$ test statistic is low and the null hypothesis may be retained. On the contrary, if they are sufficiently different, then the value of the $\chi^{2}$ test statistic is high, and the null hypothesis may be rejected [20]. Furthermore, the effects of financial literacy on debt behavior are examined using the Kruskal Wallis nonparametric $H$ test (for an explanation of the test, see [7]). The Kruskal Wallis $H$ test is based on ranked data. Once the sum of ranks has been calculated for each group, test statistic $H$ is calculated using the following equation: 


$$
H=\frac{12}{N(N+1)} \sum_{i=1}^{k} \frac{R_{i}^{2}}{n_{i}}-3(N+1)
$$

where $R_{i}$ is the sum of ranks for each group, $N$ is the total sample size and $n_{i}$ is the sample size of a particular group.

Finally, the sources of differences in debt behavior are investigated using post hoc Dunnett's test. The post-hoc analysis examines the combination of groups and reveals which groups are responsible for the difference. Dunnett's test is one of a number of post-hoc tests performed after a significant one-way analysis of variance (ANOVA), and in turn is used to determine which differences are significant. For the explanation of the test, see [7].

\subsection{The research questionnaire and sample}

The research attempted to measure the effects of financial literacy on debt behavior of Croatian financial consumers. The sample comprised of people living in Croatia, mainly in the city of Zagreb and the County of Zagreb, between the ages of 20-79 years. The questionnaire was conducted with a judgmental sample of 30 respondents living in Zagreb to test the clarity of questions used in the survey. Feedback from the sample was used in finalizing the structured questionnaire, which was conducted during April and May 2014. Data was collected using an adapted financial literacy scale developed in previous studies [12]. The instrument has been used to measure basic financial literacy in several countries previously. Three constructs namely inflation, compound interest and risk awareness were measured. Table 1 explains the rationale for including the different constructs in the questionnaire.

The measure used to determine the level of indebtedness was the number of loans taken out. The last part of the questionnaire included socio-demographic variables of the sample (gender and monthly income per person in the household). The sampling method used was a snowball sample in line with [18]. For snowball samplings, see [21]. The questionnaire was administered in the form of an internet survey sent to e-mail addresses of randomly chosen respondents who were asked to forward the survey to their acquaintances. After conducting the survey, multivariate statistical methods were used. 


\begin{tabular}{|c|c|}
\hline Section/construct & Rationale \\
\hline Inflation & $\begin{array}{c}\text { To assess knowledge of fundamental economic concepts for } \\
\text { bank saving decisions and competence in basic financial } \\
\text { numeracy. }\end{array}$ \\
\hline Compound interest & $\begin{array}{l}\text { To identify the basis for investment knowledge and test } \\
\text { mathematical reasoning. }\end{array}$ \\
\hline Risk awareness & $\begin{array}{c}\text { To test investment knowledge and knowledge of risk } \\
\text { diversification, }\end{array}$ \\
\hline Demographics & $\begin{array}{c}\text { To describe the sample in terms of the different } \\
\text { demographic profiles }\end{array}$ \\
\hline
\end{tabular}

Table 1: Rationale for including the different constructs in the questionnaire

The final questionnaire consisted out of 3 parts: 1. Financial literacy, 2. Debt behavior, and 3. Socio-demographic characteristics. Financial literacy was measured using an adapted questionnaire [12] with the adaptations shown in Table 2 .

\begin{tabular}{|c|c|}
\hline Original question & Adapted question \\
\hline $\begin{array}{l}\text { Suppose you had } \$ 100 \text { in a savings } \\
\text { account and the interest rate was } 2 \% \text { per } \\
\text { year. After } 5 \text { years, how much do you } \\
\text { think you would have in the account if } \\
\text { you left the money to grow: more than } \\
\$ 102 \text {, exactly } \$ 102 \text {, less than } \$ 102 \text { ? } 3 \\
\end{array}$ & $\begin{array}{l}\text { Suppose you had HRK } 100 \text { in a savings } \\
\text { account and the interest rate was } 2 \% \text { per } \\
\text { year. After } 5 \text { years, if you left the money to } \\
\text { grow, you would have exactly HRK } 102 \text { in } \\
\text { the account. Do you think that the following } \\
\text { statement is true/false/don't know? }\end{array}$ \\
\hline $\begin{array}{l}\text { Imagine that the interest rate on your } \\
\text { savings account was } 1 \% \text { per year and } \\
\text { inflation was } 2 \% \text { per year. After } 1 \text { year, } \\
\text { would you be able to buy more than, } \\
\text { exactly the same as, or less than today } \\
\text { with the money in this account? }\end{array}$ & $\begin{array}{l}\text { If the interest rate on your savings account } \\
\text { was } 1 \% \text { per year and inflation was } 2 \% \text { per } \\
\text { year. After } 1 \text { year, would you be able to buy } \\
\text { more than today. Do you think that the } \\
\text { following statement is true/false/don't } \\
\text { know? }\end{array}$ \\
\hline $\begin{array}{l}\text { Buying a single company stock usually } \\
\text { provides a safer return than a stock } \\
\text { mutual fund. Do you think that the } \\
\text { following statement is true or false? }\end{array}$ & $\begin{array}{l}\text { Buying a government stock is usually } \\
\text { considered riskier than buying a single } \\
\text { company stock. Do you think that the } \\
\text { following statement is true or false? " }\end{array}$ \\
\hline
\end{tabular}

Table 2: Questionnaire adaptation

\section{The results and main findings}

In order to categorize the level of financial literacy of respondents in the survey, a k-means cluster analysis with predefined number of clusters (3) was used. The three clusters were developed representing high, medium and low level of financial literacy. A financial literacy continuum spanning from financially illiterate to moderately financially literate to highly financially literate was subsequently developed, and is briefly discussed as follows: 
- Low financial literacy (financially illiterate): lacking basic financial knowledge and skills (those who on average correctly answered 1 or none of the questions);

- Moderate financial literacy: possessing basic arithmetic and financial knowledge (those who correctly answered 2 out of 3 questions);

- High financial literacy: possessing arithmetic and financial knowledge and skills (those who correctly answered all the questions).

The number of individuals included in each cluster is shown in Table 3.

\begin{tabular}{|c|c|c|c|}
\hline \multirow{4}{*}{ Clusters of financial literacy } & Clusters & $n_{i}$ & $\begin{array}{c}\text { Initial } \\
\text { cluster } \\
\text { centers }\end{array}$ \\
\cline { 2 - 4 } & Cluster 1: High FL & 43 & 3 \\
\cline { 2 - 4 } & Cluster 2: Medium FL & 46 & 2 \\
\cline { 2 - 4 } & Cluster 3: Low FL & 11 & 0 \\
\hline
\end{tabular}

Table 3: Levels of financial literacy

From the analyzed sample, $43 \%$ of respondents are categorized as highly financially literate, $46 \%$ have a medium level of financial literacy, and $11 \%$ have a low level of financial literacy, i.e. they are considered financially illiterate.

With the purpose of determining whether a respondent's level of financial literacy differs based on gender and monthly income, a nonparametric chi-square test was applied. A person's monthly income was previously categorized into three main income groups: low income $(0-2,200$ HRK); medium income $(2,200-$ 6,600 HRK); high income (>6,600 HRK). Table 4 shows results of the conducted chi-square test.

\begin{tabular}{|c|c|c|c|c|c|c|c|c|}
\hline \multirow{2}{*}{\multicolumn{2}{|c|}{$\begin{array}{c}\text { Socio-demographic } \\
\text { variable }\end{array}$}} & \multicolumn{4}{|c|}{ FL level } & \multirow[b]{2}{*}{$\mathrm{X}^{2}$} & \multirow[b]{2}{*}{ df } & \multirow[b]{2}{*}{$\mathrm{p}$} \\
\hline & & $\begin{array}{l}\text { High } \\
(\%)\end{array}$ & Medium (\%) & $\begin{array}{l}\text { Low } \\
(\%)\end{array}$ & $\begin{array}{c}\text { Total } \\
(\%)\end{array}$ & & & \\
\hline \multirow{3}{*}{ Income } & Low Income & 17 & 25 & 6 & 48 & \multirow{3}{*}{6.547} & \multirow{3}{*}{4} & \multirow{3}{*}{0.162} \\
\hline & $\begin{array}{l}\text { Medium } \\
\text { Income }\end{array}$ & 17 & 18 & 5 & 40 & & & \\
\hline & High Income & 9 & 3 & 0 & 12 & & & \\
\hline \multirow{2}{*}{ Gender } & Female & 7 & 33 & 8 & 48 & \multirow{2}{*}{30.415} & \multirow{2}{*}{2} & \multirow{2}{*}{$0.000^{* *}$} \\
\hline & Male & 36 & 13 & 3 & 52 & & & \\
\hline
\end{tabular}

Table 4: The chi-square test results for gender and income and levels of financial literacy for respondents

Table 4 shows that the percentage of male respondents with medium income is higher in the cluster of respondents with a high level of financial literacy. According to the results from the conducted chi-square test, it appears 
that there is a no statistically significant difference in financial literacy levels with respect to the level of a person's income in a household, given that the empirical significance level $p$-value is higher than 0.05. However, the results suggest that there is a statistically significant difference among financial literacy levels with respect to gender, where the p-value is less than 0.01 , as shown in Figure 1.

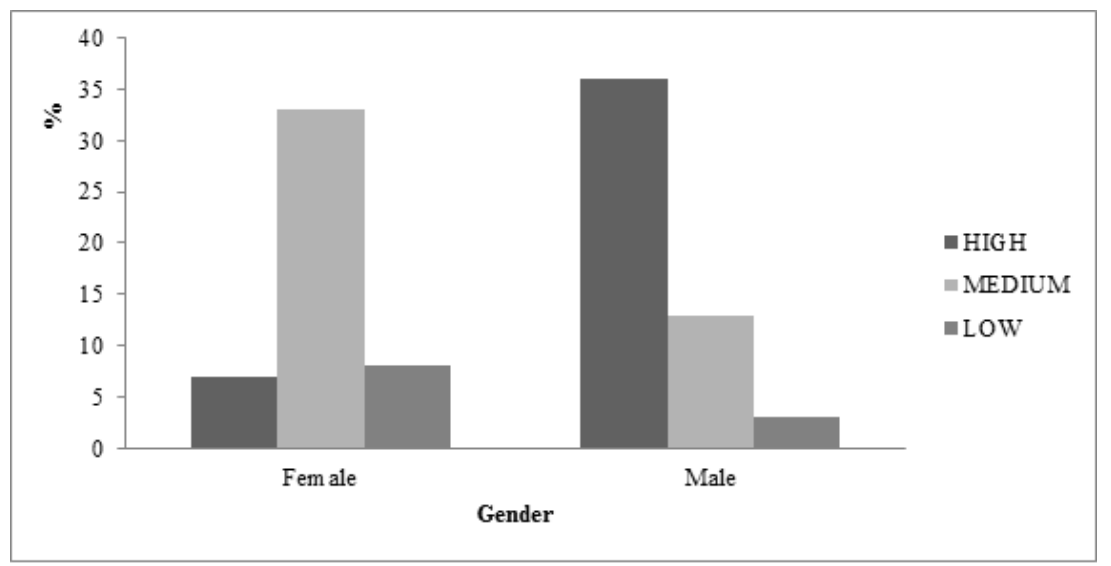

Figure 1: Difference in levels of financial literacy levels (high, medium and low) associated based on gender

Furthermore, we examined whether the debt behavior of the respondents differs with respect to the level of financial literacy and socio-demographic variables using the Kruskal Wallis $H$ test. The results of the Kruskal Wallis $H$ test are shown in Table 5. Since the p-value is less than 0.01 , we reject the null hypothesis of there being no difference between mean ranks for indebtedness. The results of the Kruskal Wallis test suggest that respondents, with respect to their different levels of financial literacy, exhibit different debt behavior. The difference in debt behavior with respect to levels of financial literacy were shown to be statistically significant.

\begin{tabular}{|c|c|c|c|c|c|c|}
\hline \multirow{4}{*}{ Indebtedness } & FL levels & $\mathrm{n}$ & Mean Rank & Chi-Square & $\mathrm{df}$ & $\mathrm{p}$ \\
\hline & High FL & 43 & 41.19 & 22.075 & 2 & $0.000^{* *}$ \\
\hline & Medium FL & 46 & 51.25 & & & \\
\hline & Low FL & 11 & 83.77 & & & \\
\hline
\end{tabular}

Table 5: The Kruskal Wallis Htest results for determining the significance in the difference between levels of financial literacy and debt behavior

To determine the effect of size, $\eta^{2}$ is calculated using following equation (see [9]): 


$$
\eta^{2}=\frac{\chi^{2}}{N-1}=\frac{22.075}{99}=22.29 \%
$$

The value of the $\eta^{2}$ value indicates that a $22.29 \%$ variability of rank scores in indebtedness is explained by financial literacy. The effect size can be interpreted as a medium (see [20]). Finally, in order to investigate the source of the confirmed difference in the debt behavior with respect to different levels of financial literacy for the respondents, we conducted a post hoc analysis using Dunnett's $C$ test. The results of the Dunnett's $C$ test are shown in Table 6 .

\begin{tabular}{|c|c|c|c|c|c|}
\hline \multirow{2}{*}{$\begin{array}{c}\text { (I) Financial literacy } \\
\text { level }\end{array}$} & $\begin{array}{c}\text { (J) Financial literacy } \\
\text { level }\end{array}$ & $\begin{array}{c}\text { Indebtedness } \\
\text { mean } \\
\text { difference } \\
(\mathrm{I}-\mathrm{J})\end{array}$ & Std. error & $\begin{array}{c}\text { Lower } \\
\text { bound }\end{array}$ & Upper bound \\
\cline { 3 - 6 } & Medium FL & -0.152 & 0.087 & -0.36 & 0.06 \\
\hline \multirow{2}{*}{ High FL } & Low FL & $-0.658^{*}$ & 0.146 & -1.06 & -0.26 \\
\hline \multirow{2}{*}{ Medium FL } & High FL & 0.152 & 0.087 & -0.06 & 0.36 \\
\cline { 2 - 6 } & Low FL & $-0.505^{*}$ & 0.161 & -0.93 & -0.08 \\
\hline \multirow{2}{*}{ Low FL } & High FL & $0.658^{*}$ & 0.146 & 0.26 & 1.06 \\
\cline { 2 - 6 } & Medium FL & $0.505^{*}$ & 0.161 & 0.08 & 0.93 \\
\hline
\end{tabular}

* indicates that the mean difference is significant at a $5 \%$ level

Table 6: Dunnett's test results for determining the source of difference in the borrowing behavior with respect to financial literacy level

From the above table, the difference between low and high as well as between low and medium level of financial literacy is statistically significant, while the difference between a medium and high level of financial literacy is not statistically significant.

\section{Conclusion}

Excessive indebtedness presents an important and widespread problem that endangers the financial wellbeing of many individuals and households. A poor level of financial literacy is one of the factors that may influence debt behavior and contribute to an increase in indebtedness. The findings of this research suggest that respondents, with respect to varying levels of financial literacy exhibit different debt behavior. Thus, respondents with a low level of reported financial literacy, i.e. financially illiterate respondents are expected to demonstrate worse debt behavior, i.e. are more indebted than consumers with medium and high levels of financial literacy. The level of disposable income per household member was found to be statistically insignificant in relation to different levels of financial literacy. On the other hand, levels of financial literacy were found to be statistically significantly different with respect to a 
respondent's gender. The results of this research conform to previous research and support the significance of financial literacy in determining a consumer's debt behavior.

Due to limited financial resources and time, this study was conducted using a snowball sample and on a limited number of people, so the results of this study may not adequately represent the total population in Croatia. Moreover, it is important to emphasize that the questions from [12] developed to determine basic financial literacy were used in the analysis. Thus, future research should include questions developed to test not only basic financial literacy but also sophisticated financial literacy. In addition, future research should increase the number of respondents included in the study and the analysis should be conducted using a random sample which adequately representing the overall Croatian population. Therefore, research on the impact of financial literacy on debt behavior should be conducted at a national level, which is the recommendation for economic policy makers in Croatia.

\section{Acknowledgment}

This work has been fully supported by the Croatian Science Foundation under the project STRENGTHS no. 9402.

\section{References}

[1] Agarwal, S., Dricsoll, J. C., Gabaix, X. and Laibson, D. (2008). Learning in the credit market. National Bureau of Economic Research. Working paper No. 13822.

[2] Bejaković, P. (2010). Osobna prezaduženost: problemi i rješenja (Private Indebtedness: Problems and Solutions). Institut za javne financije (Institute of Public Finance).

[3] Bernheim, B. D., Garrett, D. M. and Maki, D. (2001). Education and saving: The long-term effects of high school financial curriculum mandates. Journal of Public Economics, 87(7), 1487-1519. doi:10.3386/w6085.

[4] Courchane, M. J. and Zorn, P. M. (2005). Consumer literacy \& credit worthiness. http://www.chicagofed.org/cedric/files/2005_conf_paper_session3_courchane. pdf [Accessed on January 12, 2014].

[5] Croatian National Bank (2014). Financial stability. No. 13, Year 7.

[6] Dynan, K. E. (2009). Changing household financial opportunities and economic security. Journal of Economic Perspectives, 23, 49-68. doi:10.2139/ssrn.1508864.

[7] Field, A. (2009). Discovering Statistics using SPSS, 3rd Ed. Thousand Oaks: Sage.

[8] Gathergood, J. (2012). Self-control, financial literacy and consumer overindebtedness. Journal of Economic Psychology, 33(3), 590-602. doi:10.1016/j.joep.2011.11.006.

[9] Green, S. B. and Salkind, N. J. (2008). Using SPSS for Window and Macintosh: Analyzing and Understanding Data, 5th Ed. New Jersey: Pearson Prentice Hall. 
[10] Hair, J. F., Black, W. C., Babin, B. J. and Anderson, R. E. (2010). Multivariate Data Analysis, 7th Ed. Pearson Education, Inc. New Jersey: Upper Saddle River.

[11] Herceg, I. and Šošić, V. (2010). The anatomy of household debt build up: What are the implications for the financial stability in Croatia? The Sixteenth Dubrovnik Economic Conference, Croatian National Bank.

[12] Lusardi, A. and Mitchell, O. (2006). Financial literacy and planning: implications for retirement wellbeing. Pension Research Council, Working Paper. The Wharton School.

[13] Lusardi, A. and Tufano, P. (2009). Debt literacy, financial experiences, and overindebtedness. National Bureau of Economic Research. Working paper No. 14808. doi:10.3386/w14808.

[14] Lusardi, A., Mitchell, O. S. and Curtoi, V. (2010). Financial literacy among the young. Journal of Consumer Affairs, 44, 358-380.

[15] Moore, D. (2003). Survey of financial literacy in Washington State: Knowledge, behavior, attitudes, and experiences. Social and Economic Sciences Research Center, Technical Report 03-39. Washington State University.

[16] Oxera (2004). Are UK households over-indebted? Association for Payment Clearing Services, British Bankers' Association, Consumer Credit Association and the Finance and Leasing Association. London: Oxera.

[17] Servon, L. J. and Kaestner, R. (2008). Consumer financial literacy and the impact of online banking on the financial behavior of lower-income bank customers. Journal of Consumer Affairs, 42(2), 271-305. doi:10.1111/j.1745-6606.2008.00108.x.

[18] Sevim, N., Temizel, F. and Sayilir, Ö. (2012). The effects of financial literacy on the borrowing behaviour of Turkish financial consumers. International Journal of Consumer Studies, 573-579. doi:10.1111/j.1470-6431.2012.01123.x.

[19] Stango, V. and Zinman, J. (2009). Exponential growth bias and household finance. The Journal of Finance, 64(6), 2807-2849. doi:10.1111/j.1540-6261.2009.01518.x.

[20] Tabachnick, B. G. and Fidell, L. S. (2007). Using Multivariate Statistics, 5th Ed. Boston: Pearson, Allyn and Bacon.

[21] Goodman, L. A. (1961). Snowball sampling. Annals of Mathematical Statistics, $32(1), 148-170$ 